\section{The Michigan Research} Libraries Triangle (MRLT), a consortium of Michigan State University, the University of Michigan, and Wayne State University libraries, has been awarded a three-year grant from the U.S. Department of Education's Title II-A program to electronically link its online catalogs and related files. The $\$ 300,000$ grant will allow the MRLT to build upon the links among the three research libraries to provide library services to other Michigan residents and businesses via dial access, and to other libraries through statewide library networking.

\section{Oberlin College Library has been award-} ed a $\$ 150,000$ grant from the Charles E. Culpeper Foundation to support new collection preservation initiatives. The funds will be used over a three-year period to select books and other materials that are acidic to be sent for deacidification treatment or reformatting.

\section{The State University of New York (SUNY)}

Council of Library Directors has been awarded a grant of $\$ 147,730$ from the SUNY Office of Educational Technology. A pilot test using SUNYNet and the NOTIS X39.50 interface at the University of 13uffalo will provide online access to Wilson periodicals index/abstract databases, the ERIC database, and the monographic collections of three university centers using NOTIS. The project is expected to lay the groundwork for substantial SUNY-wide shared collection management and for future document delivery studies.

Also at SUNY, the State University College at Geneseo, in conjunction with SUNY Plattsburgh, the State University Institute of Technology at Utica/Rome, Monroe Community College, and SUNY New Paltz, has received $\$ 27,750$ from the SUNY Office of Educational Technology to purchase ARIEL software to be used in improving the interlibrary loan system. The new system will provide for document transmission over the Internet, and will result in cost reduction, more efficient use of staff, increased access to information, faster deliv- ery, and higher-quality documents.

\section{The University of Michi-}

gan has been awarded a twoyear grant from the U.S. Department of Education under the Foreign Periodicals Program to develop a nationally prominent and accessible collection of periodicals that chronicles the worldwide resurgence of Islam. The budget for the first year of the grant is $\$ 74,000$. The project will allow the university library to extend the scope of its current collections relating to Islam through purchasing scarcely held journals, newspapers, newsletters, and underground political publications in both Western and vernacular languages.

The University of Michigan Library has also been awarded a second year of funding from the U.S. Department of Education's Title II-C program for a project to catalog 5,500 retrospective serial titles from the Labadie Collection in the Special Collections Library. The budget for year two of this project is $\$ 81,850$. The Labadie Collection, a gift from Joseph A. Labadie, who was known as Detroit's "gentle anarchist," is known for its extensive materials on radical history in the U.S. In recent years, the collection has expanded to include substantial holdings in civil rights, the student protest and anti-war movements of the turbulent sixties, modern anarchist and Trotskyist literature, as well as material on gay liberation, radical feminism, pacifism, amnesty, and the antinuclear movements.

\section{The University of Nebraska-Lincoln Li-} braries and the Nebraska State Historical Society have been funded by the National Endowment for the Humanities Division of Preservation and Access to participate in the

Ed. note: Entries in this column are taken from library neusletters, press releases, and other sources. To ensure that your grant and acquisition neus is considered for publication, write to: Grants $\&$ Acquisitions, C\&RL News, 50 E. Huron St., Cbicago, IL 60611-2795. 
U.S. Newspaper Program to preserve and provide access to all newspapers ever published in the U.S. Funding for the three-year project totals $\$ 498,631$. The grant will be used to cata$\log$ the significant newspaper collections of the two agencies, including most newspapers published in Nebraska from its territorial days to the present as well as a unique collection of Czech-American newspapers.

\section{The University of Tennessee, Knoxville,}

Libraries have been granted $\$ 46,883$ by the National Endowment for the Humanities to survey Tennessee newspapers in preparation for a subsequent cataloging and preservation project. The addition of Tennessee brings to 47 the number of states, and two territories, participating in the U.S. Newspaper Program.

\section{Acquisitions}

\section{The papers of Dr. Horace J. McMillan, a} local area physician, community leader, and civil rights advocate, have recently been deposited with the California Ethnic and Multicultural Archives at the University of California, Santa Barbara, as part of its Africana component. The materials are an important record of Santa Barbara's first African American medical general practitioner and local civil rights advocate who made an enduring impact on civic affairs in Santa Barbara. As a community leader and activist, McMillan was a champion of affordable housing for lowincome and minority people and was a primary mover in improving the quality of health services, housing, employment, and education in the Santa Barbara community.

\section{The papers of Nobel Prize-} winning author Isaac Bashevis Singer have been acquired by the Harry Ransom Humanities Research Center at the University of Texas at Austin from

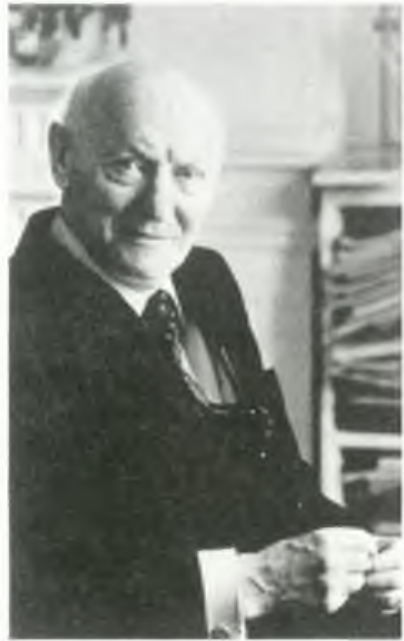

Isaac Bashevis Singer c. 1974 and notes, as well as manuscripts for much of Singer's published works and several unpublished and untranslated works of fiction and drama. Also among the materials are page proofs, manuscripts, and other prepublication materials for Meshugab, Singer's newly discovered posthumous novel that was published serially in 1981-83. There are also many personal photographs.

\section{An extensive collection of news clippings} about the 1989 Exxon Valdez oil spill in Alaska is now available in the Research Library of the Mariner's Museum in Newport News, Virginia. The materials from Michael Coumbe, a resident of Alaska-nearly 8,000 clippings taken mostly from Alaska newspapers-have been photocopied onto acid-free paper and bound into 55 volumes arranged chronologically from March 1989 to August 1990. The library has also acquired monographs on the oil spill to broaden its holdings on the disaster.

\section{The archives of PEN American Center have}

been acquired by the Department of Rare Books and Special Collections of Princeton University Libraries. Since its founding in 1922 to promote friendship and cooperation among poets, playwrights, editors, essayists, and novelists, the center has become very active in the struggle for freedom of expression and a free press, and against arbitrary censorship and imprisonment of writers. Among the archives are letters from writers Thomas Mann, Sinclair Lewis, John Dos Passos, Pearl Buck, John O'Hara, and Henry Miller dealing with everything from defense of intellectual freedom to applications for membership. Of particular interest are files pertaining to the political problems of writers under Nazi Germany, communist regimes, and military dictatorships in Greece, Latin America, and other places.

\section{Over 1,000 books on} games and gaming have been acquired from a private collector by the University of Nevada, Las Vegas (UNLV). The collection, which includes many European im- the author's widow, Alma Singer, and a group of individual Texas donors. The archive contains correspondence, photographs, clippings, 
prints dating from the 16th century, greatly extends the university's holdings in this area. The purchase was funded by the UNLV Foundation, the College of Hotel Administration, and the Library's Endowments.

\section{Materials relating to the Los Angeles} riots of 1992 are being archived at the University of Southern California's Doheny Memorial Library by librarian Anthony Anderson. The material includes the Christopher Commis- sion Report of 1991, along with 67 boxes of materials relating to the commission's investigation of the Los Angeles Police Department following the 1991 beating of motorist Rodney King. Also included are the Webster Commission archives, 58 boxes of materials on the city's handling of the riots, plus more than 40 additional reports, books, and related government and privately printed documents. The collection even includes transcripts of sermons given from Los Angeles pulpits following the riots.

\section{(LIaison cont. from page 254)}

- Participate in university orientation programs for teaching assistants, research assistants, and international and graduate students. Train students who assist faculty with their research

- Provide current bibliographic services for special research needs such as Selected Dissemination Information, table of contents, and current awareness services.

\section{Integrate the faculty into all stages of the collection development process.}

- Advise faculty about how they can participate in the selection process.

- Ensure faculty are aware of the library collection's strengths and weaknesses. Compile and distribute appropriate journal lists, new acquisitions lists, and library research handbooks and topic guides when appropriate.

- Inform faculty about budgetary and allocation issues.

- Encourage faculty to participate in decisions on materials acquisition, retrospective purchasing, conversion of materials into other formats, and replacement of missing materials. Obtain advice from departmental liaisons on the acquisition of expensive titles. Send information on newly published journal titles to appropriate faculty for purchase evaluation.

- Consult with departmental liaisons and other appropriate faculty on cancellation and evaluation of serials originally recommended by them or in their subject area. Keep faculty informed throughout the cancellation process.

III. Become familiar with the curriculum, reading requirements of undergraduate students, thesis topics of graduate students, and the research interests of faculty.

- Obtain information about academic priorities within departments. Supplement data from catalogs and other institutional sources with information obtained from questionnaires.
- Develop a standardized form to gather information about the department(s) for which you are responsible. The form may include items such as: 1) faculty size, 2) size of student population: undergraduate and graduate students, 3) new programs, 4) new courses, 5) new faculty members, 6) new research interests, 7) new research centers or labs.

- Develop a standardized questionnaire form to gather information about individual faculty: Use the questionnaire to set up profiles of faculty research interests. The following items may be included: 1) professional subject interests, 2) current research projects, 3) courses being taught, 4) other responsibilities, 5) foreign languages read, 6) academic rank.

IV. Develop subject expertise and keep current in your fields.

- Attend lectures and symposia.

- Read current works in your field.

- Talk to faculty about research, teaching, and service activities.

V. Cooperate with other librarians and library units in liaison relationships.

- Share information with subject specialists and public services librarians with responsibilities in similar academic areas.

- Regularly communicate with subject specialists working in overlapping or interdisciplinary areas.

- Exchange information with librarians involved in user education and bibliographic instruction.

- Bring users' comments or suggestions about library online information systems and concerns on library technical issues to technical services librarians.

- Elicit the support of library administrators in stressing the importance of liaison relationships. 


\section{SIIRS \\ Your a Pearl}

Providles

in $\overline{\mathbb{E}_{4}}$ erry

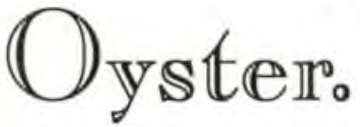

Not every oyster produces a pearl. You could look through thousands of oysters to find just one beautiful pearl. Doing research can be like trying to find a pearl in a sea full of oysters. But every search in a SIRS CD-ROM database produces a treasure trove of hits, because every one of our articles contains a pearl.

At SIRS, we believe it's what's inside that counts. So all the articles and documents on SIRS Researcher* and SIRS Government Reporter** CD-ROM programs are carefully chosen by the 25 members of our research staff. They look for the best and most informative articles on a wide range of important subjects. SIRS provides you a pearl in every oyster. For a 60-day no-obligation preview, call 1-800-232-SIRS.

* Formerly SIRS Combined Text \& Index CD-ROM.

** Selected full-text Government Documents.
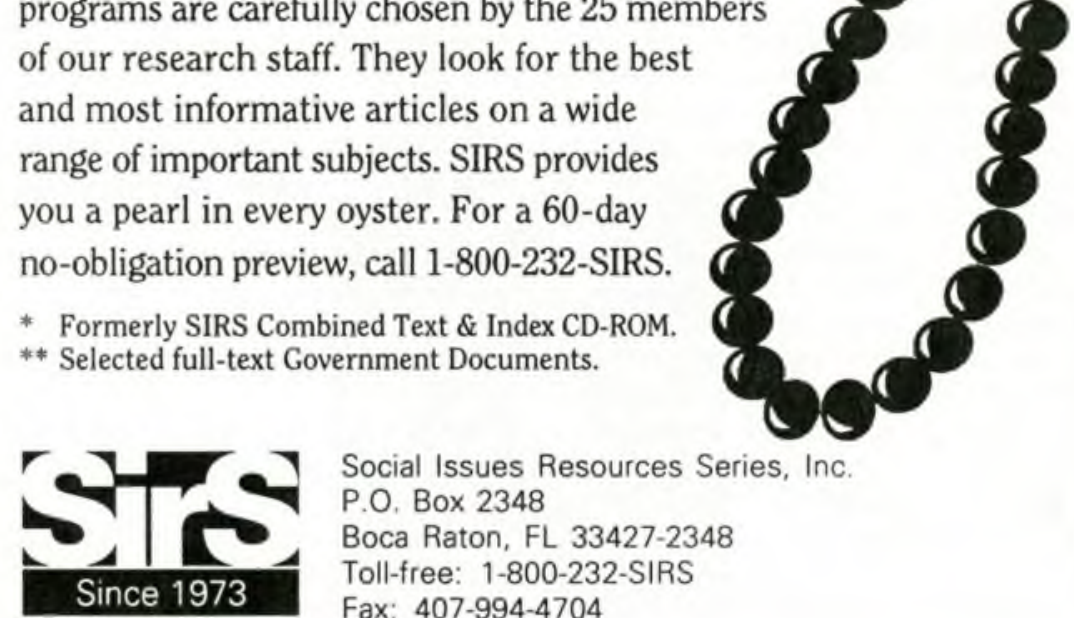

Social Issues Resources Series, Inc

P.O. Box 2348

Boca Raton, FL 33427-2348

Toll-free: $1-800-232-$ SIRS

Fax: $407-994-4704$ 